http://journal.uinsgd.ac.id/index.php/biodjati

\title{
CHARACTERIZATION OF PLANT GROWTH PROMOTING RHIZOBACTERIA (PGPR) ON Capcissum annum
}

\author{
Indah Juwita Sari*1 ${ }^{*}$ Indria Wahyuni ${ }^{2}$, Rida Oktorida Khastini ${ }^{3}$, Ewi Awaliyati ${ }^{4}$, \\ Andriana Susilowati ${ }^{5}$, Enggar Utari ${ }^{6}$, I Nyoman Pugeg Aryantha ${ }^{7}$
}

Received : July 30, 2021

Accepted : October 08, 2021

DOI: 10.15575/biodjati.v6i2.13191

1,2,3,4,5,6 Department of Bi-

ology Education, Faculty of

Teacher Training and Education,

Universitas Sultan Ageng Tirtayasa,

Serang, Indonesia, 42117

${ }^{7}$ Department of Biology, School of Life Sciences and Technology, Institut Teknologi Bandung, Bandung, Indonesia, 40116

email:

*1indahjuwitasari@untirta.ac.id

2indriawahyuni@untirta.ac.id

3rida.khastini@untirta.ac.id

4ewiawal31@gmail.com

5andrianasusilowati@gmail.com

'enggar.utari@untirta.ac.id

7nyoman@sith.itb.ac.id

*Corresponding author
Abstract. Plant Growth Promoting Bacteria Rhizobacteria (PGPR) is one of the potential bacteria to enhance of Capsicum annuum through inhabitation the growth of pathogenic fungi. This study aimed to characterize PGPR in chili plants (Capsicum annuum). $P G P R$ was isolated from the soil habitat of the red chili plant in Cilegon, Indonesia. Screening was then carried out with the dual culture method on Petri dishes and tested through in vivo method on the red chili plant. The selected bacteria were characterized morphologically, biochemically, and physiologically. The results revealed that there were 14 single isolates of bacteria from the roots of the red chili plants. The five single bacterial isolates, namely Azostobacter, Azospirillum, Pseudomonas, Serratia, and Beijerinckia have good potential as PGPR based on multiple culture screening by producing clear zones and positively effect the growth of chili plants.

Keywords: Capsicum annuum, Characterization, Chilli Plants, Dual Culture, PGPR.

\section{Citation}

Sari, I. J., Wahyuni, I., Khastini, R. O., Awaliyati, E., Susilowati, A., Utari, E. \& Aryantha, I. N. P. (2021). Characterization of Plant Growth Promoting Rhizobacteria (PGPR) on Capcisum annum. Jurnal Biodjati, 6(2), 255-263.

\section{INTRODUCTION}

Indonesia is a country that is rich in agricultural products, including horticulture. The most cultivated horticulture plant is the red chili plant (Capsicum annuum L.). According to BPS (2016), centers of red chili production in Indonesia are located in West Java, Aceh, North Sumatra, Bali, Banten, South Sulawesi, and D. I. Yogyakarta. Based on these data, Banten Province is one of the center areas of red chili production in Indonesia.

Anthracnose is a disease causes severe damage to adult fruits in the field (Saxena et al., 2016), including chili plant causing declined in production. Colletotrichum truncatum (capsici), Colletotrichum gloeosporioides, Colletotrichum acutatum are species that caused anthracnose disease in red chili plants originated from the fruit (Than et al., 2008; Saxena et al., 2014). Anthracnosis causes extensive pre and post-harvest damage to chili, caused by anthracnose lesions. Many post-harvest fruit diseases do not show symptoms until the fruit is ripe. Typical symptoms of anthracnose disease are wet fruit 


\section{JURNAL BIDDJATI}

http://journal.uinsgd.ac.id/index.php/biodjati

with a production of pink to orange conidial mass, circular or angular concave lesions that could occur in leaves, fruit, and stems (Than et al., 2008). Biological control techniques can be used to control the anthracnose (Colletotrichum sp.) and optimizing the chili production. Microorganisms that naturally associated with plant roots or better known as PGPR can improve growth and control plant diseases (Batool \& Altaf, 2017).

Several studies have been done mainly investigate the role of PGPR in chili plants to inhibit anthracnose fungal. Thilagam \& Hemalatha (2019) found that Streptomyces violaceoruber can be applied as a biological fertilizer and biocontrol agent to grow chilies against $C$. capsici fungal pathogen attack. Sutariati \& Wahab (2010) also found Bacillus spp., P. fluorescent, and Serratia spp. can inhibit the growth of anthracnose pathogens. B. subtilis exhibited sufficient antibiosis capability due to its good inhibitory performance against $C$. capsici (Rajkumar et al., 2018). Application of bio fungicides using Streptomyces spp. exhibited the increase in chili plant growth parameters such as plant height, plant stem fresh/dry weight, root fresh/dry weight, root length, and fruit yield (Suwan, 2018).

In this study, we used a dual culture method for screening PGPR that can inhibit the growth of anthracnose pathogens on chili plants. Dual culture methods provide a way of preliminary screening to exclude environmental factors that may impact practical biocontrol. So, we can observe an antagonist and pathogen interaction using in vitro observation (Bunbury-Blanchette \& Walker, 2019). Sari \& Aryantha (2021) used dual culture as an initial screening to get the indigenous Mushroom Growth Promoting Bacteria (MGPB) increase the growth of Volvariella volvacea. Besides, Rupela et al. (2003) used the dual culture method to get the potential microorganisms suppressing fungal plant pathogens as this methodcould visualize the characteristic zone of no growth in the petri dish grown beside each other on a culture plate.

\section{MATERIALS AND METHODS}

\section{Isolation of PGPR Bacteria}

As much as $1 \mathrm{~g}$ of soil attached to the root surface was put into an Erlenmeyer containing $100 \mathrm{ml}$ of sterile distilled water (10-1 dilution) and homogenized. The suspension obtained was diluted to $10^{-2}-10^{-6}$. Homogenization was carried out repeatedly using vortex in each dilution stage. The pour plate method was then carried out to inoculate the sample (Cappuccino \& Sherman, 2004). The bacterial culture obtained was incubated in a room aof $27^{\circ} \mathrm{C}$ for 24 hours. Every colony that grows was then isolated to make pure culture.

\section{Isolation of Pathogenic Fungi}

Chili plants that showed disease symptoms were collected from the field. The symptomatic plant fruits were sterilized with $5 \%$ sodium hypochlorite for 10 minutes, then cultured on a PDA medium. the cultures were incubated at room temperature $\left(28^{\circ} \mathrm{C}\right)$ for 48 hours. Growing colonies were then transferred into new plates and subcultured several times to obtain pure isolates (Cappuccino \& Sherman, 2004). Furthermore, Koch's postulate test was performed on the pathogenic fungus.

\section{Screening Using Dual Culture}

Dual culture is an initial selection method to obtain the potential isolatesas biological agents. A single isolate of bacteria that have been grown on NB media for 24 hours was grown on PDA media using pour 


\section{JURNAL BIDDJATI}

http://journal.uinsgd.ac.id/index.php/biodjati

plate method. After the PDA wassolid, pieces of pathogenic fungi with a diameter of 0.5 $\mathrm{cm}$ were inoculated in a petri dish containing PDA medium. The culture was incubated at a temperature of $26^{\circ}-28^{\circ} \mathrm{C}$ for 48 hours. For each bacterial isolate, the test was repeated three times. The observation was carried out for 24-48 hours to see the inhibition zone or clear zone around the growth of pathogenic fungi.

\section{Selected Bacterial Testing on Chili Seeds (In Vivo)}

The surface of chili seeds were sterilized using 70\% ethanol solution for 5 minutes. The seeds were then put into $2 \% \mathrm{NaOCL}$ solution for three minutes and washed using sterile aquadest 3 times. The chili seeds were then soaked in selective bacterial culture and water as a control. The chili seeds were placed in sterile filter paper placed in a petri dish for seven days. The selected rhizosphere bacterial culture with a density of $108 \mathrm{CFU}$ $\mathrm{ml}^{-1}$ was used and dissolved. The bacteria were inoculated by watering the zeolite medium with a gap between seeds of $10 \mathrm{~cm}$. The parameter observed was the height of the chili plant (Widiyanti et al., 2016).

\section{Characterization of PGPR}

The parameter observed to characterize PGPR were the color, shape, edges, and elevation of colonies. Gram staining, motility test, and catalase testing were also conducted. Lastly, the samples were adjusted used Bergey's Manual of Determinative identification book (Holt et al., 1994).

\section{RESULTS AND DISCUSSION}

There were 14 single isolates of bacteria obtained from the roots of the red chili plants. . The result of observations on the characteristics of the bacterial colonies are presented in Table 1.

Table 1. The result of observations single isolates

\begin{tabular}{|c|c|c|c|c|c|}
\hline Solate Name & Colony of Colony & Colony Morfology & Surface & Gram & $\begin{array}{c}\text { Cell } \\
\text { Morfology }\end{array}$ \\
\hline$\overline{\mathrm{A}}$ & White (opaque) & Round shaped & Flat & & Bacil \\
\hline B & Pink & Irregular & Flat & - & Coccus \\
\hline $\mathrm{C}$ & Red & Irregular & Flat & - & Coccus \\
\hline $\mathrm{D}$ & Red & Irregular & Convex - & & Coccus \\
\hline $\mathrm{E}$ & White (opaque) & Round shaped & Convex - & & Bacil \\
\hline $\mathrm{F}$ & White & Irregular & Flat & - & Coccus \\
\hline G & Yellow & Irregular & Flat & - & Bacil \\
\hline $\mathrm{H}$ & White & Round shaped & Flat & - & Bacil \\
\hline I & White & Round shaped & Convex - & & Coccus \\
\hline $\mathrm{J}$ & White (opaque) & Round shaped & Flat & - & Bacil \\
\hline K & White (opaque) & Irregular & Flat & - & Bacil \\
\hline $\mathrm{L}$ & White (opaque) & Irregular & Flat & + & Bacil \\
\hline M & White (opaque) & rregular & Flat & + & Bacil \\
\hline
\end{tabular}

Figure 1. is a red chili infected with a pathogenic fungus. Based on observation, the symptoms that appear in red chili are a color change around the area of infection, skin tissue damage and wet. Based on these symptoms, red chili may be affected by Fusarium wilt by Fusarium oxysporum (Bai et al., 2018). Figure 2 is pathogenic fungi isolate from infected 


\section{JURNAL BIODJATI}

http://journal.uinsgd.ac.id/index.php/biodjati

chilies that have characteristic of white color mycelium that change to be orange after more than 48 hours. Moreover, Figure 3 shows a spore of Fusarium oxysporum. According to Joshi et al. (2012), the Fusarium oxysporum has thin macroconidia and generally walled 3-5 septate, addition the chlamydospores were both rough and smooth-walled, generally intercalary, and sometimes terminal.

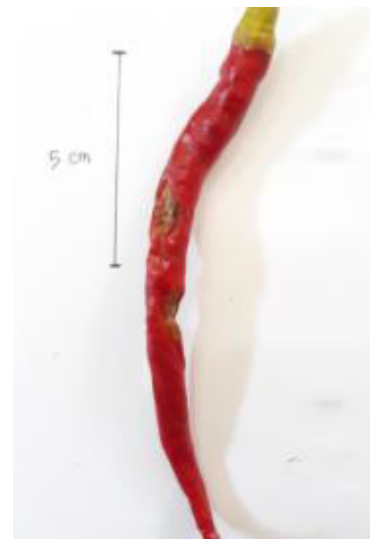

Figure 1. A red chili infect ed with a pathogenic fun-

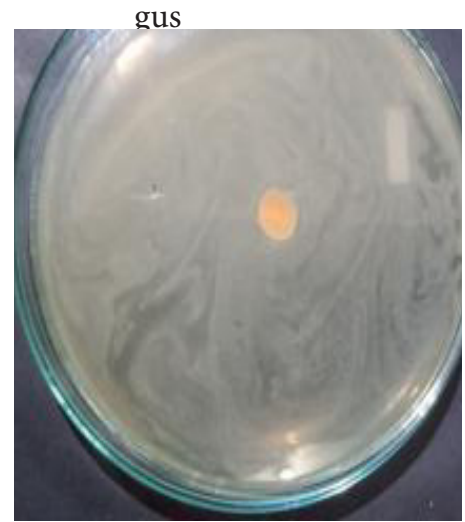

Figure 4 . The absence of a clear zone

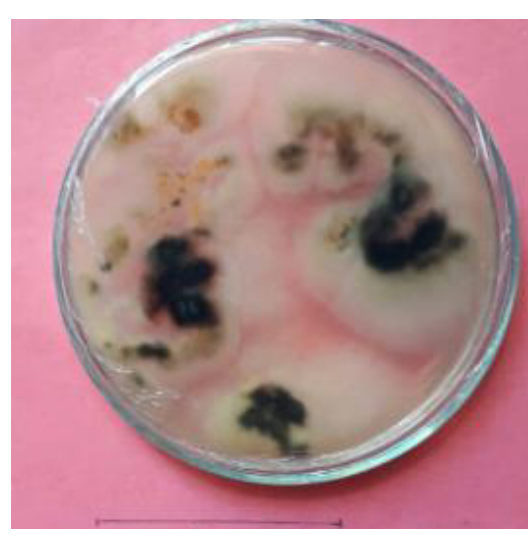

Figure 2. Pathogenic fungi isolate from infected chilies

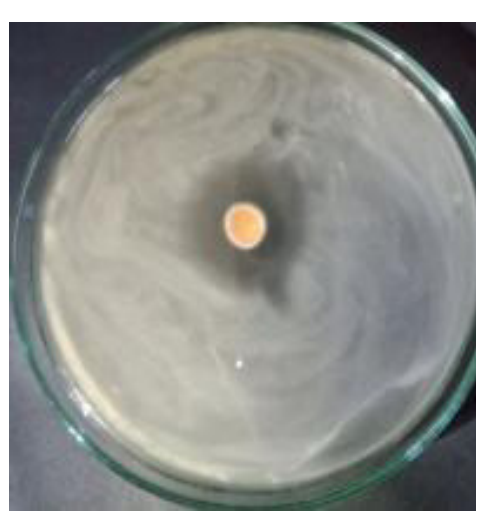

Figure 5a. isolate have a large clear zone

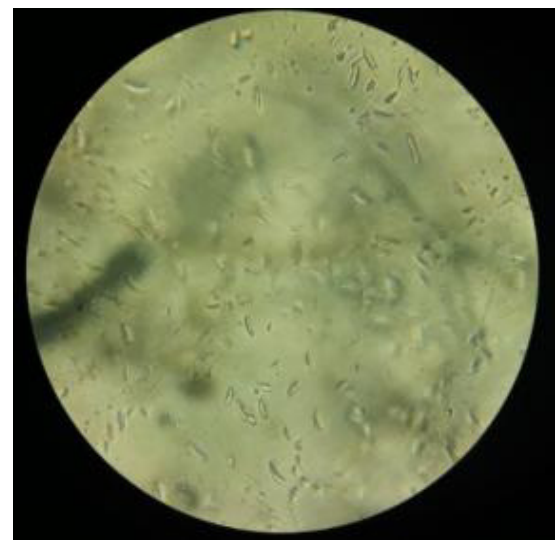

Figure 3. Spore of Fusarium oxysporum (Magnification 100x)

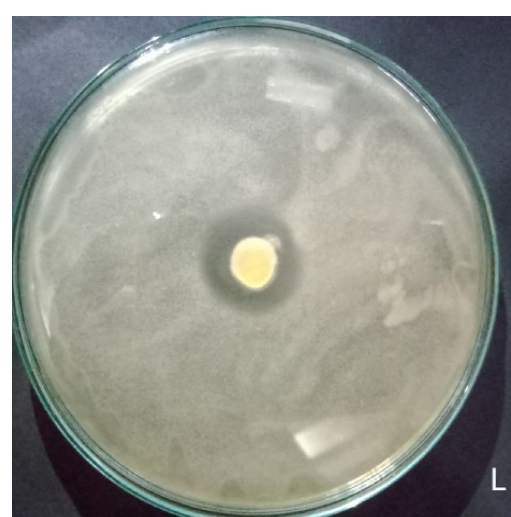

Figure 5b. isolate have a small clear zone
The dual culture results between pathogenic fungi and bacterial isolates to obtain PGPR bacteria are characterized by the presence of a clear zone around the pathogenic fungal mycelium on PDA (Figure 4). The absence of a clear zone on the presence of bacteria means that the bacteria are unlikely to have an impact on the growth of the pathogenic fungal mycelium (Figure 4). While the emergence of clear zones may indicate the presence of bacteria inhibiting the growth of pathogenic fungal mycelium (Figure $5 \mathrm{a}$ and 5b). According to Zivkovic et al. (2010) and Mmbaga et al. (2018), the emergence of a clear zone is one of the bacterial mechanisms responsible for suppressing fungal pathogens, including competition, antibiotics, and metabolite production. The dual culture in Figure 5a has a large clear zone than that in Figure 5bThis is due to the different ability of PGPR to inhibit the pathogenic fungal mycelium. Shobha \& Kumudini (2012) found 


\section{JURNAL BIDDJATI}

http://journal.uinsgd.ac.id/index.php/biodjati

that the various mechanism of PGPR inhibits pathogenic fungi, such as the active enzymes, toxic metabolites from PGPR that can damage the fungal cellular walls.

The results of the growth of chili seeds treated with selective pathogenic fungi and bacteria are presented in Figure 6. Based on observations, bacterial isolates that gave the effect to growth of chilli seeds are bacterial isolates with code of A, B, E, G, H, I, K, and
$\mathrm{N}$. The application of bacterial isolates results in higher plant height compared to control. Schillaci et al. (2019) stated that some nutrient-supplying bacteria at the root of the rhizosphere (rhizobacteria) are PGPR. This group of bacteria has many roles, including tethering nitrogen $(\mathrm{N})$, producing IAA, dissolving phosphate, and inhibiting plant disease.

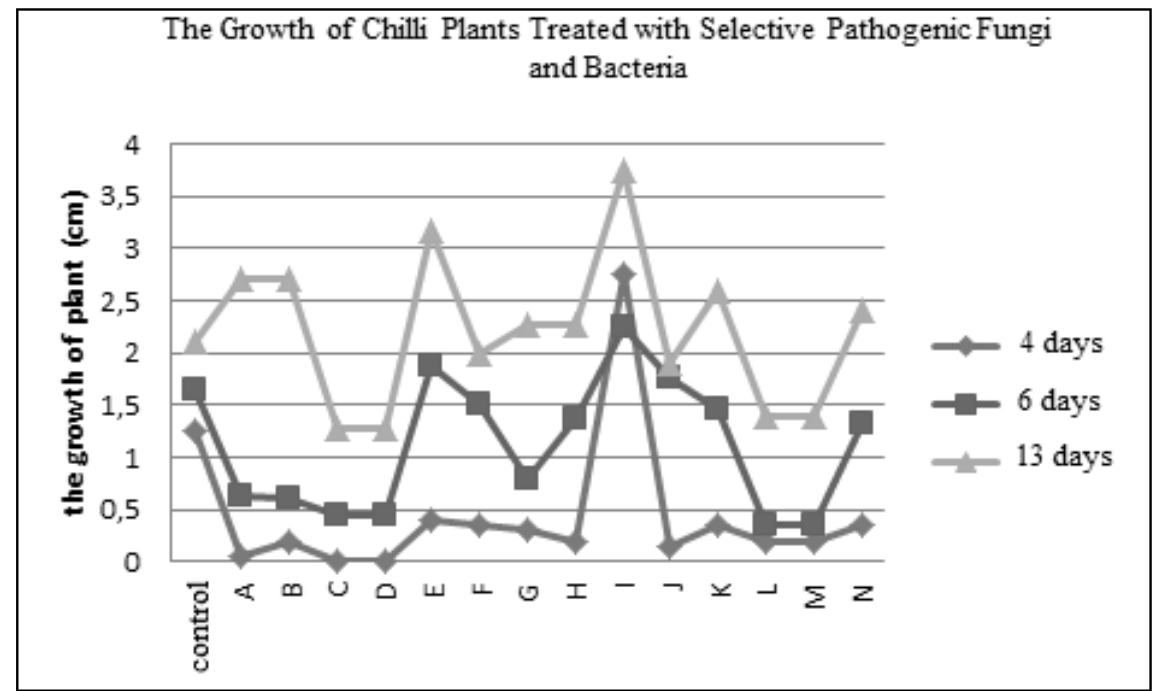

Figure 6 The chart of the growth of chilli seeds treated with selective pathogenic

Among fourteen bacterial isolates that had passed the dual culture test and produced a clear zone that also positively affected the growth of chili plants from the seed phase, are the bacterial isolates with codes A, B, E, $\mathrm{I}$, and $\mathrm{N}$ (Figure 7). We then identified those bacterial isolates based on morphological observations in Table 1 and Figure 7. Isolate A has a small rounded colony, flat elevation, shiny colony surface, flat edge of the colony with white opaque color, and a bacillus (stem) cell shape and was gram-negative bacteria (Figure 7a). Meanwhile, the results on biochemical activity test showed that isolate A was positive in the catalase test, negative in the indole test, motile, and was aerobic. The results obtained indicated that isolate Jurnal Biodjati 6(2):255-263, November 2021 might belong to the genus Azotobacter. The result is in accordance with Bergey's Manual of Determinative Bacteriology 9th edition, which explains that the genus Azotobacter has the characteristics of stem-shaped cells, gram-negative, motile, aerobic, can break down nitrogen, positive in catalase tests, and are generally classified as non-symbiotic (Holt et al., 1994). Azotobacter has the ability as $\mathrm{N}$ fixation by producing phytohormones, so Azotobacter could be used to enhance the growth of plants as PGPR (Kanchana et al., 2013).

Based on the results of morphological observations (Figure $7 \mathrm{~b}$ ), isolate $\mathrm{B}$ showed the characteristics of a rounded-shape colony, flat elevation shiny colony surface. 


\section{JURNAL BIDDJATI}

http://journal.uinsgd.ac.id/index.php/biodjati

The edge of the colony is flat with pink, has a cocus shape, and is gram-negative. Meanwhile, biochemical activity test showed characteristics of the positive catalase test, the positive indole test, motile, and aerotolerant. The results obtained indicated that isolate $\mathrm{B}$ might belong to the genus Azospirillum. This is in accordance with Bergey's Manual of Determinative Bacteriology 9th edition, which explains that the genus Azospirillum has the characteristics of fibroid-shaped cells, pink, gram-negative, motile, and can break down nitrogen (Holt et al., 1994). Azospirillum has defense mechanisms during abiotic stresses through inducing systemic tolerance, mediated by antioxidants, osmotic adjustment, production of phytohormones, and defense strategies such as the expression of pathogenesis-related genes (Fukami et al., 2018).

The isolate $\mathrm{E}$ has the shape of a rounded colony, convex elevation, the shiny surface colony, the edge of the colony have milky white color, had the shape of bacilli (stem) cells and gram-negative (Figure 7c). Meanwhile, observations of the biochemical activity test showed isolate $\mathrm{E}$ has characteristics of positive catalase testing, negative indole testing, motile, and aerotolerant interactions. The results obtained indicated that isolate E was included in the genus Pseudomonas. This is in accordance with Bergey's Manual of Determinative Bacteriology 9th edition which explains that the genus Pseudomonas has the characteristics of stem-shaped cells, gram-negative, mobile, aerobic, and positive catalase tests (Holt et al., 1994). According to (Munir et al., 2019), Pseudomonas can be facilitators for siderophore, I-3-AA, ammonia production, phosphate solubilization, and tomatoes' growth in greenhouse conditions.

Based on morphological observations (Figure 7d), isolate I showed characteristics of rounded colony shape, convex elevation, shiny colony surface, flat edge colony with clear color, a bacillus (stem) cell shape and was gram negative. Meanwhile, biochemical activity test revealed that Isolate I was positive in catalase test, the negative indole test, motile and were anaerobic in nature. The results obtained indicated that isolate I might belong to the genus Serratia. This is in accordance with Bergey's Manual of Determinative Bacteriology 9th edition, which explains that the genus Serratia has the characteristics of rod-shaped cells, gramnegative, usually motile with peritric flagella, anaerobic facultative, positive in catalase tests and negative indole tests (Holt et al., 1994). Martinez et al. (2018) stated that Serratia strains have the ability as biofertilizers and could increase the root collar diameter, height, relative chlorophyll content, biomass, and nitrogen content of raulí plantlets.

The isolate $\mathrm{N}$ showed characteristics of rounded colony shape, convex elevation, shiny colony surface, flat edge of the colony with milky white color,bacillus (stem) cell shape and was gram negative (Figure 7e). Meanwhile, the results on biochemical activity test showed this isolate was the negative catalase test, the negative indole test, motile, and aerobic. Based on the results obtained indicates that isolate $\mathrm{N}$ might belong to the genus Beijerinckia. This is in accordance with Bergey's Manual of Determinative Bacteriology 9th edition, which explains that the genus Beijerinckia has the characteristics of stem-shaped cells, gram-negative, motile or non-motile, can fix nitrogen under aerobic and also microaerobic conditions, and positive catalase tests (Holt et al., 1994). Beijerinckia is one of the PGPR that has benefits for nitrogen fixation (Vejan et al., 2016). 


\section{JURNAL BIDDJATI}

http://journal.uinsgd.ac.id/index.php/biodjati

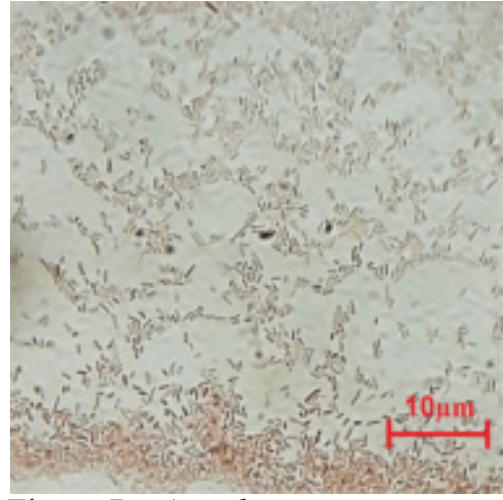

Figure 7a. Azotobzcter sp.

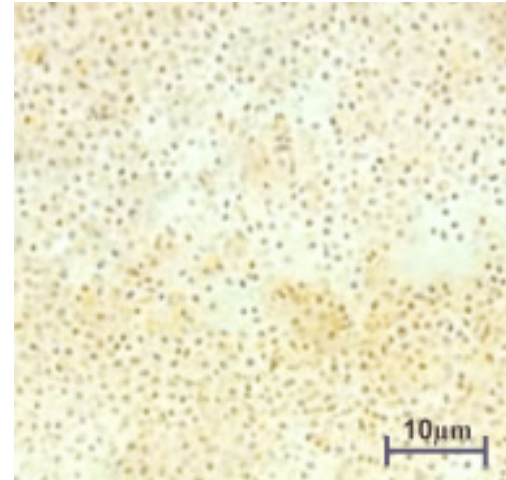

Figure 7b. Azospirillum sp

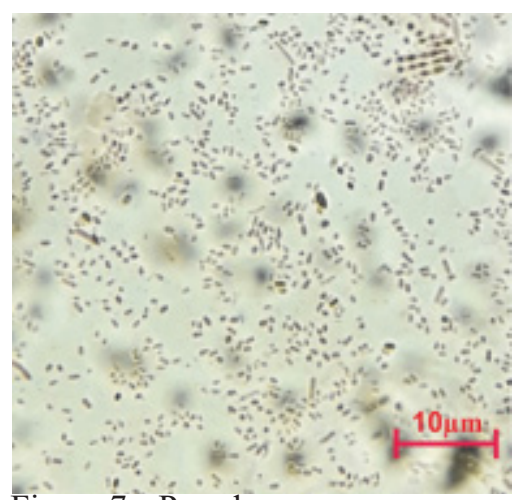

Figure 7c. Pseudomonas sp.

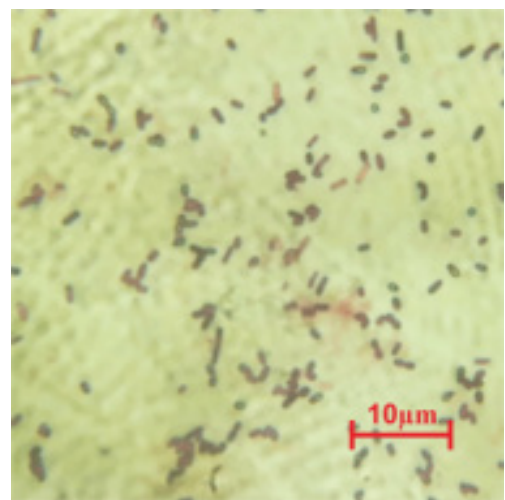

Figure 7d. Serratta sp.

\section{ACKNOWLEDGEMENTS}

Authors thank LPPM Universitas Sultan Ageng Tirtayasa who has funded this research through Penelitian Kerjasama antar Perguruan Tinggi (Pekerti).

\section{REFERENCES}

Badan Pusat Statistik [BPS]. (2016). Produktivitas Cabai Besar. Retrieved from http://www.pertanian.go.id/Data5tahun/HortiASEM2016(pdf)/Produksi\%20Cabai\%20Besar.pdf.

Bai, A.T., Ruth, Ch., Gopal, K., Arunodhayam, K., Priya, B. T. \& Ramakrishna, M. (2018). Survey and Identification of Fusarium Wilt Disease in Chilli (Capsicum annuum L.). Int.J.Curr.Microbiol, 7(6), 1073-1078.

Batool, S. \& Altaf, M. A. (2017). Plant Growth Jurnal Biodjati 6(2):255-263, November 2021

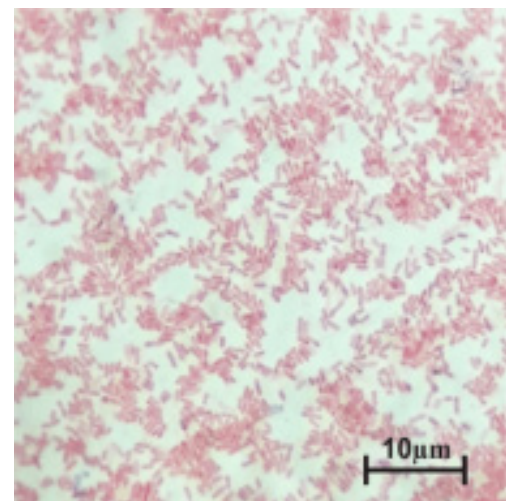

Figure 7e. Beljerinckia sp.

Promoting Rhizobacteria (PGPR) Reduces Application Rates of Fertilizers in Chili (Capsicum frutescens L.) Cultivation. J Hortic, 4(215), 2376-0354,

Bunbury-Blanchette, A. L. \& Walker, A. K. (2019). Trichoderma Species Show Biocontrol Potential in Dual Culture and Greenhouse Bioassays Against Fusarium Basal Rot of Onion. Biological Control, 130, 127-135.

Cappuccino, J.G. \& Sherman, N. (2004). Microbiology: A Laboratory Manual. Singapore: Pearson Education.

Fukami. J., Cerezini, P. \& Hungria, M. (2018). Azospirillum: Benefits that Go Far Beyond Biological Nitrogen Fixation. AMB Express, 8(1), 73.

Holt, J. G., Kreig, N. R., Sneath, P. H. A., Staley, J. T. \& Williams, S. T. (1994). Bergey's Manual of Determinative Bacteriology 9th. United States of America: 


\section{JURNAL BIDDJATI}

http://journal.uinsgd.ac.id/index.php/biodjati

Williams \& Wilkins.

Joshi, M., Srivastava, R., Sharma, A. K. \& Prakash, P. (2012). Screening of Resistant Varieties and Antagonistic Fusarium Oxysporum for Biocontrol of Fusarium Wilt of Chilli. Journal of $J$ Plant Pathology \& Microbiology, 3(5), 1-6.

Kanchana, D., Jayanthi, M., Saranraj, P. \& Sujitha, D.. (2013). Prevelence of Azotobacter sp. in Chilli (Capsicum annuum L.) Rhizosphere Soil of Cuddalore District, Tamil Nadu, India. International Journal of Microbiological Research, 4(3), 296-299.

Martínez O. A., Encina, C., Tomckowiack, C., Droppelmann, F., Jara, R., Maldonado, C., Muñoz, O., Fraile, P. G. \& Rivas, R. (2018). Serratia Strains Isolated From The Rhizosphere of Rauli (Nothofagus Alpina) in Volcanic Soils Harbour PGPR Mechanisms and Promote Raulí Plantlet Growth. J. Soil Sci. Plant Nutr, 8(3), 804-819.

Mmbaga, M. T., Gurung, S. \& Maheshwari. (2018). Screening of Plant Endophytes as Biological Control Agents Against Root Rot Pathogens of Pepper (Capsicum annum L.). J Plant Pathol Microbiol, 9(3), 1-8.

Munir. I., Bano, A. \& Faisal, M. (2019). Impact of Phosphate Solubilizing Bacteria On Wheat (Triticum aestivum ) in The Presence of Pesticides. Braz. J. Biol, 79(1), 29-37.

Rajkumar, K., Naik, M. K. Amaresh, Y. S. \& Chennappa, G. (2018). Bioefficacy of Bacillus subtilis Against Major Pathogen of Chilli Colletotrichum capsici Causing Fruit Rot of Chilli. Int.J.Curr. Microbiol. App.Sci, 7(7), 2681-2686.

Rupela, O. P., Gopalakrishnan, S., Krajewski, M. \& Sriveni, M. (2003). A Novel Method For The Identification And
Enumeration of Microorganisms With Potential for Suppressing Fungal Plant Pathogens. Biology and fertility of soils, 39(2), 131-134.

Sari, I. J. \& Aryantha, I. N. P. (2021). Screening and Identification of Mushrooms Growth Promoting Bacteria on Straw Mushrooms (Volvariella volvacea). Journal of Tropical Biodiversity and Biotechnology, 6(1), 60618.

Saxena, A., Raghuvanshi, R. \& Singh, H. B. (2014). Molecular, Phenotypic And Pathogenic Variability in Colletotrichum Isolates of Subtropical Region in North Eastern India, Causing Fruit Rot Of Chillies. J. Appl. Microbiol, 117, 1422-1434.

Saxena, A., Raghuwanshi, R., Gupta, V. K. \& Singh, H. B. (2016). Chilli Anthracnose: The Epidemiology and Management. Frontiers in Microbiology, 7, 1527.

Schillaci, M., Gupta, S., Walker, R. \& Roessner, U. (2019). The Role of Plant Growth Promoting Bacteria in Growth of Cereals under Abiotic Stresses. Root Biology - Growth, Physiology, and Functions. Retrieved from https://www. intechopen.com/chapters/67771.

Shobha, G. \& Kumudini, B. S. (2012). Antagonistic effect of the Newly Isolated PGPR Bacillus spp. on Fusarium oxysporum. Int J Appl Sci Eng Res, 1(3), 463-474.

Sutariati, G. A. K. \& Wahab, A. (2010). Isolasi dan Uji Kemampuan Rizobakteri Indigenous Sebagai Agensia Pengendali Hayati Penyakit pada Tanaman Cabai. J. Hort, 20(1), 86--95.

Suwan. N., To-anun, C., Soytong, K. \& Nalumpang, S. (2012). Evaluation of Streptomyces-biofungicide to Control Chili Anthracnose in Pot Experiment. Journal of Agricultural Technology, 


\section{JURNAL BIDDJATI}

http://journal.uinsgd.ac.id/index.php/biodjati

8(5), 1663-1676.

Than, P. P., Prihastuti, H., Phoulivong, S., Taylor, P. W. J. \& Hyde, K. D. (2008). Chilli Anthracnose Disease Caused by Colletotrichum species. Journal of Zhejiang University Science B, 9(10), 764-778.

Thilagam, R. \& Hemalatha, N. (2019). Plant Growth Promotion and Chilli Anthracnose Disease Suppression Ability of Rhizosphere Soil Actinobacteria. Journal of Applied Microbiology, 126 (6), 1835-1849.

Vejan. P., Abdullah, R., Khadiran, T., Ismail, S. \& Boyce, A.N. (2016). Role of Plant Growth Promoting Rhizobacteria in Agricultural Sustainability-A Review.
Molecules, 21(5), 573.

Widiyanti, D., Pujiyanto, S., Suprihadi, A. \& Setyowati, M.. (2016). Penapisan dan Pemanfaatan Rhizobakteri Tanaman Jagung (Zea Mays) Sebagai Inokulan Pemacu Tumbuh Tanaman. Jurnal Biologi, 5(3), 80-89.

Živković, S., Stojanović, S., Ivanović, Ž., Gavrilović, V., Popović, T. \& Balaž, J. (2010). Screening of Antagonistic Activity of Microorganisms Against Colletotrichum Acutatum And Colletotrichum Gloeosporioides. Arch. Biol. Sci., Belgrade, 62(3), 611-623. 